\title{
Bacterial vaginosis in women attending STD clinic: diagnostic criteria and prevalence of Mobiluncus spp
}

\author{
ANDERS HALLÉN, * CARL PÅHLSON, † URBAN FORSUM
}

From the ${ }^{*}$ Department of Dermatology and Venereology, $\dagger$ Institute of Clinical Bacteriology, University Hospital, University of Uppsala, Uppsala, and the $\ddagger$ Institute of Clinical Bacteriology, Karolinska Institute, Huddinge Hospital, Stockholm, Sweden

SUMMARY The diagnostic criteria of bacterial vaginosis (BV) and the prevalence of Mobiluncus spp as detected by monoclonal antibodies were investigated in all new women patients attending the sexually transmitted disease (STD) clinic in Uppsala during a four month period. Of 455 patients, 164 fulfilled the generally accepted criteria for BV, but in 57 of them simultaneous infection with a recognised pathogen was diagnosed. BV was thus the only clinical diagnosis in $107(24 \%)$ of the women. The sniff test and clue cells in the wet smear were the two criteria most relevant for the diagnosis of BV. The sniff test was positive in $95 \%$ (156) of the 164 patients with BV and negative in all other cases. The corresponding figure for the clue cells was $98 \%$ (160 of 164), but clue cells were also detected in 19 patients without BV. Though $99 \%$ (162) of women with BV had a vaginal $\mathrm{pH}$ of more than 4.5 , so did 83 women without BV. Only $59 \%(96)$ of women fulfilling the criteria of BV had a characteristic discharge.

Mobiluncus spp were present in 20\% (90) of the 455 women and in 50\% (53) of the 107 women with BV only. Of the 90 Mobiluncus spp isolates, $M$ curtisii comprised $44 \%$ (40), M mulieris $34 \%$ (31), and both strains together $21 \%$ (19). Mobiluncus spp were detected with monoclonal antibodies in 35 women who had no motile curved rods on wet smear microscopy. Furthermore, Mobiluncus spp were often detected in women infected with recognised pathogens, as well as in a few women without signs of genital infection.

Bacterial vaginosis (BV) is a common diagnosis in women complaining of vaginal discharge. Criteria for the syndrome have been defined by Eschenbach et al. ${ }^{1}$ The aetiology is not established, but studies show that the vaginal microbial flora in women with $\mathrm{BV}$ is altered from lactobacilli to mixed anaerobes. ${ }^{23}$ Among the different anaerobic bacteria occurring in samples from women with BV, the genus Mobiluncus (containing the two species $M$ mulieris and $M$ curtisii) has attracted specific interest ${ }^{4}$ as it has been isolated almost exclusively from women with BV. ${ }^{56}$ In contrast, the first organism associated with BV, Gardnerella vaginalis, has been isolated from about $50 \%$ of clinically healthy women. ${ }^{78}$ The position of Mobi-

Address for reprints: Dr Anders Hallén, Department of Dermatology and Venereology, University Hospital, S-751 85 Uppsala, Sweden.

Accepted for publication 12 March 1987 luncus spp in the ecology or even aetiology of BV has been difficult to establish, partly because the commonly used culture methods are very labour intensive and have been reported to give suboptimal isolation rates. ${ }^{910}$

We have described the production of monoclonal antibodies against protein antigens occurring in $M$ curtisii and Mmulieris. ${ }^{11}$ These monoclonal antibodies have been used successfully for the direct detection of Mobiluncus spp in a small series of clinical specimens of vaginal discharge using immunofluorescence. ${ }^{11}$ Monoclonal antibodies to Mobiluncus spp were used in the study published here to define the prevalence of Mobiluncus spp in women attending a sexually transmitted disease (STD) clinic. The design of the study allowed us to evaluate the clinical criteria used for the diagnosis BV as well as to investigate the occurrence of Candida spp, Trichomonas vaginalis, Neisseria gonorrhoeae, and Chlamydia trachomatis in patients fulfilling the critieria for BV. 
Patients and methods

\section{PATIENTS}

From November 1984 to February 1985 all new women attending the STD clinic at the University Hospital in Uppsala were included in the study. The clinic is the only STD department in an area serving about 150000 people, about 20000 of whom are university students. As far as the local police authorities know there is no prostitution in the city, and no woman in the study identified herself as a prostitute. A total of 455 women aged 16 to 51 (mean age 25) was studied, $187(41 \%)$ of whom had one sexual partner during the previous year and $13(3 \%)$ had had six partners or more.

\section{METHODS}

After a standardised interview all patients had a routine gynaecological examination. To detect Ngonorrhoeae, C trachomatis, Tvaginalis and Candida spp routine laboratory methods were used. $N$ gonorrhoeae was cultivated on chocolate agar and GC base agar (Difco, England) supplemented with $1 \%$ Isovitalex (BBL, Scotland). ${ }^{11}$ Chlamydiae were isolated by a modification of the method of Ripa and Mårdh. ${ }^{12}$ T vaginalis was isolated on Diamond's medium. ${ }^{13}$ Fungal cultivation was processed as outlined in the Manual of clinical microbiology, ${ }^{4}$ and yeasts were identified as $C$ albicans by the demonstration of germ tube production three hours after incubation in serum at $35^{\circ} \mathrm{C}$. The preparation and use of monoclonal antibodies for detecting Mobiluncus spp in clinical samples has been described previously. ${ }^{15}$

Smears were taken from the cervix with a cotton tipped swab and from the urethra using a $1 \mu \mathrm{l}$ inoculating loop (NUNC, Denmark), and examined by direct microscopy. Urethritis was defined as more than 10 polymorphonuclear leucocytes (PMNL) per field $(\times 1000)$ in the stained smear from the urethra. ${ }^{16}$ Cervicitis was defined as mucopus in the cervical os and more than 10 PMNL per field $(\times 1000)$ in the stained smear from the cervix. ${ }^{17}$ Wet smears and smears to be stained by monoclonal antibodies to Mobiluncus spp were taken from the vaginal fornices with a $10 \mu \mathrm{l}$ inoculating loop (NUNC, Denmark). Wet smears were examined by light microscopy $(\times 400)$ for the presence of yeast cells, $T$ vaginalis, epithelial cells and clue cells, PMNL, lactobacilli, and motile curved rods. A wet smear was considered to show inflammation if the number of PMNL exceeded the number of epithelial cells. The other criteria looked for were recorded as showing positive or negative results.

The sniff test (amine test) was performed with $10 \%$ potassium hydroxide, and results were recorded as positive or negative. The vaginal $\mathrm{pH}$ was measured using $\mathrm{pH}$ paper graded in steps of $\mathbf{0 . 2}$ (Merck). For a diagnosis of BV the patient should fulfill at least three of the following criteria: vaginal $\mathrm{pH}$ of more than 4.5 , sniff test positive, clue cells in the wet smear, or characteristic vaginal discharge on examination. ${ }^{1}$

A woman was considered to have no signs of genital infection if there was no urethritis, cervicitis, or condylomata, the wet smear contained fewer PMNL than epithelial cells, and none of the specific pathogens listed above was identified.

\section{Results}

\section{DIAGNOSIS OF BV}

Table 1 shows the clinical diagnoses of all 455 women (based on history, physical findings, and results of isolation of microbial pathogens) in relation to the fulfilment of criteria for BV (in the presence or absence of other diagnoses) and the detection of Mobiluncus spp using immunofluorescence on direct vaginal smears. Apart from the 107 women with a clinical diagnosis of BV only, other micro-organisms were identifed in 57 patients who also fulfilled the criteria for BV. Most of the women with gonorrhoea and trichomoniasis and more than half of those with chlamydial infections fulfilled the criteria for BV. Eight women with a clinical diagnosis of BV had cervicitis, 14 urethritis, and 31 had an inflammatory wet smear.

Table 2 shows the relevance of the individual criteria in the scoring system for diagnosing BV in the 164 patients with BV, $59 \%$ of whom had the characteristic vaginal discharge. Table 2 also shows the number of patients with $\mathrm{BV}$ as a proportion of those who fulfilled one criterion for BV. Only $66 \%$ (162) of the 245 women with a vaginal $\mathrm{pH}$ of more than 4.5 and $79 \%(96)$ of the 121 with a characteristic discharge had BV.

Table 1 Clinical diagnoses of 455 women in relation to fulfilment of criteria for bacterial vaginosis (BV) (in the absence and presence of other diagnoses) and detection of Mobiluncus spp using monoclonal antibodies

\begin{tabular}{lrrl}
\hline & & $\begin{array}{l}\text { No (\%) } \\
\text { fulfilling criteria } \\
\text { for BV }\end{array}$ & $\begin{array}{l}\text { No (\%) with } \\
\text { Mobiluncus } \\
\text { spp }\end{array}$ \\
\hline Clinical diagnosis* & No (\%) & $14(10)$ \\
Bacterial vaginitis & $148(33)$ & $12(8)$ & $53(50)$ \\
Chlamydial infection & $107(24)$ & $107(100)$ & $14(22)$ \\
Gonorrhoea & $65(14)$ & $37(57)$ & $3(43)$ \\
Trichomoniasis & $7(2)$ & $5(71)$ & $3(33)$ \\
Condyloma & $9(2)$ & $7(78)$ & 0 \\
Non-specific urethritis & $21(5)$ & 0 & $3(14)$ \\
Non-specific cervicitis & $19(4)$ & $14(67)$ & $3(16)$ \\
Other diagnoses & $25(5)$ & 0 & 0 \\
Healthy & $64(14)$ & 0 & $3(5)$ \\
\hline
\end{tabular}

*Some patients had more than one diagnosis. 
Table 2 Number of women with bacterial vaginosis ( $B V)$ satisfying one criterion for $B V$ out of 455 women

\begin{tabular}{lll}
\hline Clinical criterion & No (\%) & $\begin{array}{l}\text { No (\%) } \\
\text { fulfilling criterion } \\
\text { for } B V\end{array}$ \\
\hline Vaginal pH > 4.5 & $245(54)$ & $162(66)$ \\
Clue cells present & $179(39)$ & $160(89)$ \\
Sniff-text positive & $156(34)$ & $156(100)$ \\
Characteristic discharge & $121(27)$ & $96(79)$ \\
Lactobacilli absent from wet smear & $164(36)$ & $150(91)$ \\
\hline
\end{tabular}

OCCURRENCE OF MOBILUNCUS SPP IN PATIENTS WITH BV

Mobiluncus spp were present in 20\% (90) of the 455 women (table 1) compared with 50\% (53) of the 107 women with a final diagnosis of BV only; $M$ mulieris in $17, M$ curtisii in 20 , and both Mobiluncus species concomitantly in 16.

In addition to the information on the relation between wet smear and immunofluorescence, to be commented on later, table 3 shows that of the 164 women with BV, including the 57 with a clinical diagnosis based on the finding of a recognised pathogen, $73(45 \%)$ harboured Mobiluncus spp. Of the 90 Mobiluncus spp found in all 455 women, M curtisii was found in $40(44 \%)$, M mulieris in $31(34 \%)$, and the two species together in $19(21 \%)$.

To evaluate the usefulness of wet smear detection of motile curved rods for the presumptive identification of vaginal Mobiluncus spp, results on wet smear microscopy were compared with the detection of Mobiluncus spp in vaginal smears by immunofluorescence (table 3). Wet smear microscopy and immunoflurescence gave positive results in $51 \%$, and immunofluorescence in another $33 \%$. Table 3 also shows that motile curved rods were seen in the wet smear in 12 cases where immunofluorescence did not detect Mobiluncus spp. When additional slides from these 12 patients were examined further by immunofluorescence and Gram staining, two possible false negative results were found, as Gram negative curved rods were seen in stained smears but no Mobiluncus spp were detected by immunofluorescence. No curved rods or Mobiluncus spp could be seen in smears from the other 10 patients.

Table 3 Findings of Mobiluncus spp by immunfluorescence and of motile curved rods by wet smear microscopy in 455 women and in the 164 with bacterial vaginosis (BV)

\begin{tabular}{llllll}
\hline & \multicolumn{2}{l}{$\begin{array}{l}\text { Rods in total study } \\
\text { population }(n=455)\end{array}$} & & \multicolumn{2}{l}{$\begin{array}{l}\text { Rods in women fulfilling } \\
\text { criteria for } B V(n=164)\end{array}$} \\
\cline { 2 - 3 } Mobiluncus spp & Present & Absent & & Present & Absent \\
\hline$M$ mulieris only & 19 & 12 & 19 & 6 \\
$M$ curtisii only & 23 & 17 & 23 & 9 \\
Both species & 13 & 6 & 13 & 3 \\
Neither species & 12 & & 12 & \\
\hline
\end{tabular}

Seventeen women without BV had Mobiluncus spp on testing with monoclonal antibodies, but were wet smear negative for motile curved rods: eight had M curtisii, six Mmulieris and three harboured both strains. One of these 17 patients had gonorrhoea, 11 had candidal vaginitis (all with lactobacilli in the vaginal wet smear and one with concomitant chlamydial infection), two women had cervicitis, and three were considered to be healthy.

\section{Discussion}

This study of 455 consecutive women was undertaken at the STD department of the University Hospital, Uppsala. There were a few promiscuous women in the study, but most of the women had had one or two sexual partners during the previous year, which is comparable to what is known in general about Swedish women of these age groups (Lewin B, unpublished observation).

The criteria for diagnosing BV are generally accepted, ${ }^{15}$ but the usefulness of these criteria is not uniform. The amine test and the presence of clue cells in the wet smear are both reliable indicators of BV (table 2). Almost all women with BV had a vaginal $\mathrm{pH}$ of more than $4 \cdot 5$, but in this study this was found in many women without BV. These criteria are objective and reproducible. The fourth criterion, the characteristic quality of the vaginal discharge, is subjective. Not surprisingly, therefore, it is neither sensitive nor specific, and seems to be less useful for clinical purposes. Absence of lactobacilli is part of the definition of BV proposed at the BV symposium in Stockholm 1984 and, as can be seen from table 2, this can be used as another wet smear criterion of BV together with clue cells.

In this study 164 women fulfilled the conventional criteria for BV. Evidently the criteria for BV do not exclude other infections, ${ }^{18}$ but reports on the occurrence of other microbes in patients with BV are scarce, and most authors seem to exclude infections with recognised pathogens from a diagnosis BV. In this study $8 \%$ of patients with candidal vaginitis and $57 \%$ of those with chlamydial infections had BV (table 1). Most patients with gonorrhoea and trichomoniasis also had BV. From a clinical point of view this is a problem, because there is no clear distinction between a diagnosis of BV based on the accepted criteria and a clinical diagnosis of BV, which excludes infections with recognised pathogens.

As suggested by the name, BV is not considered to be a true infection. ${ }^{19}$ Of the 107 women in this study with a clinical diagnosis of $\mathrm{BV}$, however, eight $(8 \%)$ had cervicitis, $14(13 \%)$ urethritis, and $31(29 \%)$ had an inflammatory wet smear. These inflammatory reactions were not linked to the presence of Mobi- 
luncus spp. We did not culture for Mycoplasma species in this study, though mycoplasmas have been reported in connection with BV. ${ }^{20}$ Whether these inflammatory reactions are caused by mycoplasmas or some other pathogen, or whether some cases of BV might be inflammatory, has to be studied further.

In this study 90 women had Mobiluncus spp. Of these, $55(61 \%)$ were identified as having motile curved rods in their wet smears. From a clinical point of view it seems reasonable to assume that the presence of motile rods in the wet smear indicates Mobiluncus spp. In this study there were 12 cases in which the wet smear was positive without findings by immunofluorescence. Two of these were possible false negatives on immunofluorescence, as Gram negative curved rods were found on examination of additional slides. Some other organism with a similar motion may exist in the wet smear, but so far this has not been reported. The anaerobe similar to Bacteroides ureolyticus reported by Fontaine et al., which is associated with non-gonococcal urethritis, is said to have a twisting motility. ${ }^{21}$ The prevalence of that microbe in vaginosis was not studied.

In the women studied, the prevalence of Mobiluncus spp was $20 \%$, and in those with clinical BV it was $50 \%$ (table 1). The prevalence of motile curved rods in wet smears was $22 \%$ in all the women and $50 \%$ in those with BV (table 3). These figures are compatible with what has been reported by others, ${ }^{22} 23$ and it thus seems that Mobiluncus spp are not present in all patients with BV. M curtisii is the most common species and is usually found alone. We also found more Mmulieris and more cases where both strains occurred simultaneously than reported before. $^{6}$ The detection of Mobiluncus spp using monoclonal antibodies probably gives a more representative view of the relative proportions of $M$ curtisii and $M$ mulieris compared with culture, with its very time consuming selection of colonies ${ }^{9}$ and suboptimal isolation rates. $^{622}$

Mobiluncus spp are most often found in vaginas with a disturbed ecology, primarily of women with BV. In this study, however, we found Mobiluncus spp in women with different clinical infections and also in three healthy women. We have recently reported the presence of Mobiluncus spp in the rectums of women with Mobiluncus associated BV (paper read at 2nd world congress on STD, Paris, 1986). One hypothesis is that Mobiluncus spp, like Candida spp, contaminate the vagina from the rectum, which would explain finding Mobiluncus spp in women with all kinds of genital infections as well as in healthy women.

\section{References}

1 Eschenbach DA, Bekassy S, Blackwell A, Ekgren J, Hallèn A, Wathne B. The diagnosis of bacterial vaginosis. Scand J Urol
Nephrol 1984;suppl 86:260-1.

2 Spiegel CA, Amsel R, Eschenbach D, Schoenknecht F, Holmes $\mathrm{KK}$. Anaerobic bacteria in non-specific vaginitis. $N$ Engl $J$ Med 1980;303:601-7.

3 Taylor E, Barlow D, Blackwell A, Phillips I. Gardnerella vaginalis, anaerobes and vaginal discharge. Lancet 1982;i:1376-9.

4 Spiegel CA, Roberts M. Mobiluncus gen nov, Mobiluncus curtisii subsp curtisii sp nov, Mobiluncus curtisii subsp holmesii subsp nov, and Mobiluncus mulieris sp nov, curved rods from the human vagina. International Journal of Systematic Bacteriology 1984;34:177-84.

5 Spiegel CA, Eschenbach D, Amsel R, Holmes KK. Curved anaerobic bacteria in bacterial (nonspecific) vaginosis and their response to antimicrobial therapy. J Infect Dis 1983;148:817-22.

6 Hallén A, Hjelm E, Forsum U, Påhlson C, Wallin J. Motile curved rods in women attending a STD clinic. Scand J Urol Nephrol 1984;suppl 86:153-5.

7 McCormack WM, Hayes CH, Rosner B, et al. Vaginal colonization with Corynebacterium vaginale (Haemophilus vaginalis). $J$ Infect Dis 1977;136:740-5.

8 Hjelm E, Hallén A, Forsum U, Wallin J. Anaerobic curved rods in vaginitis. Lancet 1981;ii:1353-4.

9 Hjelm E, Forsum U, Hallén A, Påhlson C, Wallin J. Primary isolation of curved rods from women with vaginal discharge. Scand J Urol Nephrol 1984;suppl 86:113-6.

10 Fox A, Phillips I. Two curved rods in non-specific vaginitis. Scand J Urol Nephrol 1984;suppl 86:93-6.

11 Morello JA, Bohnhoff M. Neisseria and Branhamella. In: Lennett EH, Balows A, Hausler WJ Jr., Truant JP, eds. Manual of clinical microbiology. 3rd ed. Washington DC: American Society for Microbiology, 1980:111-30.

12 Ripa T, Mårdh P-A. Cultivation of Chlamydia trachomatis in cycloheximide-treated McCoy cells. J Clin Microbiol 1977;6:328-31.

13 Diamond LS. The establishment of various trichomonads of animals and man in axenic cultures. J Parasitol 1957;43:488-90.

14 Silva-Hunter M, Cooper BH. Yeasts of medical importance. In: Lennett EH, Balows A, Hausler WJ Jr., Truant JP, eds. Manual of clinical microbiology. 3rd ed. Washington DC: American Society for Microbiology, 1980:562-76.

15 Påhlson C, Hallén A, Forsum U. Curved rods related to Mobiluncus: phenotypes as defined by monoclonal antibodies. Acta Pathol Microbiol Immunol Scand [B] 1986;94:113-6.

16 Wallin J, Thompson SU, Zaidi A, Wong K-H. Urethritis in women attending an STD clinic. British Journal of Venereal Diseases 1981;57:50-4.

17 Brunham RC, Paavonen J, Stevens CE, Kiviat N, Kuo C-C, Critchlow CW, Holmes KK. Mucopurulent cervicitis: the ignored counterpart in women of urethritis in men. $N$ Engl $J$ Med 1984:311:1-6.

18 Amsel R, Totten PA, Spiegel CA, Chen KCS, Eschenbach D, Holmes KK. Nonspecific vaginitis. Diagnostic criteria and microbial and epidemiological associations. Am $\mathrm{J}$ Med 1983;74:14-22.

19 Holmes KK, Spiegel C, Amsel R, Eschenbach DA, Chen KCS, Totten P. Nonspecific vaginosis. Scand J Infect Dis 1981;suppl 26:110-4.

20 Paavonen J, Miettinen A, Stevens CE, Chen KCS, Holmes KK. Mycoplasma hominis in nonspecific vaginitis. Sex Transm Dis 1983;4:271-5.

21 Fontaine EAR, Borriello SP, Taylor-Robinson D, Davies HA. Differential characteristics of a small Gram-negative anaerobe associated with non-gonococcal urethritis which morphologically resembles Bacteroides ureolyticus. Scand J Urol Nephrol 1984;suppl 86:157-65.

22 Blackwell A, Fox A, Phillips I, Barlow D. Anaerobic vaginosis (non-specific vaginitis): clinical, microbiological and therfapeutic findings. Lancet 1983;ii:1379-82.

23 Pattman RS. The significance of finding curved rods in the vaginal secretions of patients attending a genito-urinary medical clinic. Scand J Urol Nephrol 1984;suppl 86:143-6. 